\title{
Analysis of the Influence of Fundamental and External Factors on Stock Prices in Mining Sector Companies Listed on the Indonesia Stock Exchange
}

\author{
Andri Setia Putra \\ Master of Management, Sriwijaya University, Palembang, Indonesia \\ Corresponding author email: Andrisetiaputraa@gmail.com \\ Mohamad Adam \\ Lecturer of Magister Management, Economic Faculty, Sriwijaya University, Palembang, Indonesia \\ Email: mr_adam2406@yahoo.com \\ Marlina Widiyanti \\ Lecturer of Magister Management, Economic Faculty, Sriwijaya University, Palembang, Indonesia \\ Email: marlinawidiyanti68@yahoo.co.id \\ Tertiarto Wahyudi \\ Lecturer of Magister Management, Economic Faculty, Sriwijaya University, Palembang, Indonesia \\ Email: Tertiwahyudi@gmail.com
}

\begin{abstract}
This study aimed to determine the effect of liquidity ratios (LR), solvency (DER), profitability (ROE), valuation ratios $(P B V)$, inflation, and interest rates on stock prices of mining sector companies listed on the Indonesia Stock Exchange (IDX). The research sample is 41 mining sector companies with a research period from 2015-2019. The results show that the liquidity ratio (CR) and solvency (DER) have no significant effect on stock prices of mining sector companies in 2015-2019. The variable profitability (ROE), valuation ratio (PBV) was concluded to have a significant positive effect on stock prices of mining sector companies in 2015-2019. Meanwhile, inflation and interest rates have a significant adverse effect on stock prices of mining sector companies in 20152019.
\end{abstract}

Keywords---inflation, interest rate, liquidity $(C R)$, profitability $(R O E)$, rating ratio $(P B V)$, solvency $(D E R)$.

\section{Introduction}

The mining sector is one of the pillars of a country's economic development because of its role as a provider of energy resources that are indispensable for the economic growth of a country. According to Sari \& Sedana (2020), a company in the general mining industry can take the form of an integrated business in the sense that the company has an export business, the development of construction, production, and processing as a single business unit or in the form of separate businesses, each of which stands alone. Mining companies need considerable capital to explore natural resources in developing their business. For this reason, many mining companies have entered the capital market. The capital market is said to have an economic function because the market provides facilities that bring together two interests, namely those who have excess data (investors) and those who need funds.

The Indonesia Stock Exchange (ISE) is the capital market in Indonesia with the number of companies listed as of August 24, 2020, as many as 700 issuers, of which 47 are listed, including mining sector companies. Shares are one of the instruments traded on the Indonesia Stock Exchange. For companies, a high stock price will increase the 
company's value so that many investors will invest in the company, while for investors, it can increase the return/difference in the value obtained from the shares they own.

Stock prices are influenced by factors originating from within the company (internal factors), which are also often called fundamental factors and factors originating from outside the company (external factors) or technical factors. Fundamental factors come from within the company that issues shares, which are related to the company's performance appraisal, about the effectiveness and efficiency of the company in achieving its goals (Sylvester \& Ade, 2018). Fundamental and external factor analysis can help business people, government, and other users of financial statements assess the company's financial condition and prospectus. Financial ratios measure fundamental factors, while inflation and interest rates measure how much influence external factors have on stock prices (Gonçalves \& Salles, 2008; Al-Marhubi, 1997).

In previous studies, an analysis of several fundamental and external factors variables that are estimated to affect stock prices has been carried out. Widyarani (2006), Ulupui (2007), stated that the Current Ratio positively affects stock prices. While the research conducted by Restiyanti (2006), Decminar \& Widyarti (2016), mention that the Current Ratio harms stock prices. Itabillah (2012), argues that the Debt to Equity Ratio has a positive effect on stock prices. At the same time, the research conducted by Restiyanti (2006), Cathelia \& Sampurno (2016), Decminar \& Widyarti (2016), concluded that the Debt to Equity Ratio hurts stock prices. Cathelia \& Sampurno (2016), Decminar \& Widyarti (2016), concluded that Return on Equity has a positive effect on stock prices. Meanwhile, Amaliah \& Manda (2021), argues that Return on Equity does not affect stock prices.

Anggun et al. (2012), and Amaliah \& Amanda (2021), argue that Price Book Value has a positive effect on stock prices, while research conducted by Sugosha \& Artini (2020) concluded that Price Book Value harmed stock prices. Patar (2014), and Toin \& Sutrisno (2016), argue that inflation and interest rates have no significant effect on stock prices, while research conducted by Widiastuti et al. (2016), concluded that interest rates have a significant effect and inflation has no significant effect on stock prices.

\section{Research Methods}

The type of data used in this research is secondary data. We sourced from annual financial reports and share prices of mining sector companies listed on the Indonesia Stock Exchange (ISE) and the value of Inflation \& Interest Rates obtained from Bank Indonesia and the Central Statistics Agency. Forty-one companies were used as research samples with an observation period from 2015-2019. The independent variable used is the liquidity ratio measured by the current ratio (CR), the debt measures the solvency ratio to equity ratio (DER), the profitability ratio is measured by return on equity (ROE), the valuation ratio is measured by price-to-book value (PBV). Inflation, interest rates. The dependent variable of this research is the share price of mining sector companies (Sack \& Wieland, 2000; Rudebusch, 2002).

Panel data regression is used as a technique in analyzing the data. Descriptive statistics, model feasibility test (F test), and individual significance test (t-test) were also used. Panel data regression is an analysis that combines and combines time series data with cross-section data determination of this panel data regression equation through panel data model estimation. The Chow and Hausman tests were carried out to get the appropriate model estimation. The forms of the model that will be tested in this study are:

$$
\text { Ln stock price }_{i t}=\alpha+\beta_{1} \mathrm{CR}_{i t}+\beta_{2} \mathrm{DER}_{i t}+\beta_{3} \mathrm{ROE}_{i t}+\beta_{4} \mathrm{PBV}_{i t}+\beta_{5} \text { Inflation }_{i t}+\beta_{5} \text { Rate }_{i t}+\varepsilon_{\text {it }}
$$

\section{Results and Discussion}

\section{Descriptive analysis results}

Ferdinand (2014), explains that descriptive analysis aims to share illustrations of the information presented in studies. The descriptive statistics themselves, as described, are the analysis of each research variable. Each of the variables provides its description of each variable. Minimum, maximum, and average (mean) provide an overview of each variable's most minor, most significant, and average data values. 
Table 1

Descriptive statistics

\begin{tabular}{|c|c|c|c|c|c|}
\hline Variable & $\mathrm{N}$ & Minimum & Maximum & Mean & Std. deviation \\
\hline Stock Price & & 110 & 3850 & 1402 & 913.82 \\
\hline CR & & 101 & 948 & 263.38 & 163.8 \\
\hline DER & & 0.05 & 3.15 & 0.97 & 0.85 \\
\hline ROE & 50 & -26.54 & 41.29 & 7.61 & 11.93 \\
\hline PBV & & 0.05 & 4.66 & 1.11 & 0.91 \\
\hline Inflation & & 2.72 & 3.61 & 3.17 & 0.33 \\
\hline interest rate & & 4.25 & 7.50 & 5.50 & 1.29 \\
\hline
\end{tabular}

The table above presents a description of each variable with its respective values. It can be seen from the table that all variables except ROE have good data distribution based on the average value, which is greater than the standard deviation.

\section{F-test}

The best model used in this study is the fixed effect model (FEM), and the model is also free from the classical assumption problem, so the next step is hypothesis testing. The test to conclude the independent variables' effect on the dependent variable requires a model feasibility test (F test). Decision-making is based on the Prob. F value which can be seen from the statistical output. Suppose the calculated F value is more significant than the F table and the Prob. F value is less than 0.05 , and it can be concluded that all independent variables have an effect together.

Table 2

F-test results

\begin{tabular}{cc}
\hline Mark & Coefficient \\
\hline $\mathrm{F}_{\text {count }}$ & 8.381737 \\
$\mathrm{~F}_{\text {table }}$ & 2.3 \\
Sig & 0.000 \\
\hline
\end{tabular}

Source: Eviews output (processed data)

The Sig value in the table is a prob. F value shows a number below the 5\% (0.05) level. The Fount value of 8.381237 is greater than the F-table obtained from table $\mathrm{F}$ in the appendix, which is 2.3. Based on the two statements, it can be concluded that the independent variables CR, DER, ROE, PBV, inflation, interest rates have a combined effect on stock prices.

\section{Individual parameter significance test (t-Test)}

The t-test was used to measure the effect of the independent variable individually on the dependent variable. Decision-making on the level of influence is based on the probability value of the variable; if the value is below the significance level of $5 \%(0.05)$, then the variable has a significant effect. The effect of the variable can also be determined by comparing the $t$ value of the output calculation with the specified $t$ table. If the $t$ count is more significant than the $\mathrm{t}$ table, the variable is concluded to have a significant effect.

Table 2

Significance test results

\begin{tabular}{lrrrl}
\hline Variable & Coefficient & Std. Error & t-Statistics & Prob. \\
C & 8.268352 & 0.772802 & 10.69918 & 0.0000 \\
CR & 0.095358 & 0.064992 & 1.467221 & 0.1496 \\
DER & 0.257062 & 0.147394 & 1.744039 & 0.0883 \\
ROE & 1.408420 & 0.638643 & 2.205331 & 0.0328 \\
PBV & 0.311269 & 0.136913 & 2.273486 & 0.0280 \\
\hline
\end{tabular}




\begin{tabular}{lllll}
\hline INFLATION & -39.00140 & 18.77135 & -2.077709 & 0.0437 \\
INTEREST RATE & -17.99034 & 5.670579 & -3.172575 & 0.0028 \\
\hline
\end{tabular}

Source: processed data (Eviews output)

The output of random effect panel data regression where the regression equation can be made as follows:

$$
\mathrm{LNY}_{\text {stock price }}=8: 26+0.095 \mathrm{CR}+0.257 \mathrm{DER}+1.408 \mathrm{ROE}+0.3112 \mathrm{PBV}-39.0014 \text { Inflation }-17.9903 \text { interest rate }
$$

The description of the numbers in table 2 above is as follows:

a) The number value of 8.26 that appears above is a constant number known as the intercept. The constant is the value of the regression equation that intersects the $\mathrm{Y}$-axis. The value of the number 8.26 above shows the $\mathrm{Ln}$ value of the stock price if the other independent variables have a value of 0 . Since the regression equation uses the Log-Lin (Log-Linear) model, it is necessary to find the $\mathrm{Y}$ value. Data transformation using an exponential function.

b) Variable CR (current assets) has a value of Prob. 0.1496 or greater than 0.05 . The fourth column has the tcount variable value of 1.467221, smaller than the t-table 2.01669. Based on these two statements, it can be concluded that hypothesis 1 , which states that the liquidity ratio as measured by $\mathrm{CR}$ has a positive effect on stock prices, is rejected.

c) The following line is the solvency variable measured through DER (debt to equity ratio ). In the table of Prob values. DER is 0.0883 , more significant than the specified significance level of 0.05 . The table also shows the $\mathrm{t}$-count value of the variable 1.744039, smaller than the t-table 2.01669 . This statement provides a different inference from the proposed hypothesis 2 , so the hypothesis is rejected.

d) The profitability ratio as measured by ROE ( return on equity) based on the table has a value of Prob. Below the significance level of 0.0328 . The $t$-count value of the output also shows a value greater than $t$-table 2.01669, which is 2.205331 . The conclusion drawn from this statement follows hypothesis 3 , namely that ROE has a significant positive effect on stock prices. The positive direction of influence can be seen from the magnitude of the value of the $t$-statistic column, whose value is positive, not negative. The positive direction indicates that an increase in the value of ROE will impact increasing the value of stock prices as well.

e) The PBV (price to book value) variable in the table also shows the value of Prob. Below the 0.05 significance, which is 0.0280 . The t-count value of 2.273486 confirms hypothesis 4 . Namely, PBV has a significant positive effect on stock prices. A positive $t$-count value concludes that an increase in PBV will significantly affect increasing stock prices.

f) The inflation variable in the table above has a Prob value. Below 0.05 is 0.0437 , and the value of $t$ count above $t$ table is -2.077709 . The minus value on $t$ count means that the effect of inflation is opposite to the stock price. Hypothesis 5, which states that inflation has a significant negative effect on stock prices, is accepted based on the results above. An increase in inflation will decrease the stock value because the opposite effect is shown in the $t$-value of the variable.

g) The interest rate value also shows a significant negative by measuring the $t$-count value, which is -3.172575 , more significant than the $t$ table. Prob value. 0.0028 is smaller than the significance level of 0.05 . Based on these two statements, it can be concluded that interest rates have a significant adverse effect on stock prices. Hypothesis 6 is accepted where an increase in interest rates will affect and weaken the value of stock prices.

The study results conclude that liquidity, measured by current assets (CR), does not affect stock prices. The increase or decrease in CR will not affect the share price of the mining sector in the 2015-2019 period. Although the results show insignificant results, the direction of the effect shown is positive, seen from the positive $t$-count value. This result does not follow the proposed hypothesis, which estimates a significant positive effect of CR on stock prices. The results of the insignificant effect of CR are the same as the results of research conducted by Hastuti \& Sutanto (2017), Widayanti \& Colline (2017), Efrizon (2019), Halim \& Hafni (2019).

Solvency, as measured by the debt to equity ratio (DER), is also known to have no effect on stock prices based on the previous description of the research results. The results provide a statement that the size of the DER will not affect the stock price or will not affect investors in the mining sector market. The results are not following the proposed hypothesis where it is hypothesized that DER affects stock prices (van der Ploeg, 1995). The proposed hypothesis explains that the optimal value of debt managed by the company will benefit the company. Some 
investors like to invest and take risks in companies that add debt to earn high profits. The results of this study are the same as those of Rizal (2015), Sudirjo (2016), Widayanti \& Colline (2017), Efrizon (2019), Halim \& Hafni (2019).

Based on the research results, the profitability variable as measured by return on equity (ROE) has a significant positive effect on stock prices. These results indicate that an increase in ROE or company returns will increase stock prices in the market. Companies that increase their rate of return show their ability to manage the company well. These results follow the signal theory and performance theory discussed earlier, where profitability is a signal and reflects the ability shown to the market. Increased ROE offers investors a successful and efficient use of capital without involving additional equity (Ichsani \& Suhardi, 2015; Căpraru \& Ihnatov, 2014). Investors generally prefer to invest in companies whose returns continue to increase, and ROE is one of the company's signals for investors. The results of this study are not only in line with the theory used but are also in line with several previous studies that examined this matter. Research that gives the same results is the research of Widiastuti et al. (2016), Martiani (2019). As previously stated, a high ROE indicates a high potential value even though ROE is not the only assessment instrument and metric, but investors can consider ROE.

The study results conclude a significant positive effect of price to book value (PBV) on share prices of mining sector companies in 2015-2019. The statement of results is in line with the proposed theory, namely the signal theory, where PBV as a measure of firm value will attract investors to invest their capital (Niemann et al., 2008). The PBV ratio is one of the ratios to analyze the company's value by comparing the value of shares in the market to the book value of shares. PBV is used as a valuation instrument by investors to find undervalued and overvalued stocks. PBV assists investors in identifying and avoiding undervalued and overvalued companies. PBV also provides information about modest price growth or not to investors, although this ratio has limitations. The research results show that an increase in PBV will increase stock prices due to market sentiment. The company's high value is none other than because the market provides it. The market gives this because the company's financial performance is good, and the potential for increasing company profits is good in future financial projections. The results of this study are in line with research conducted by (Itabillah, 2012).

Inflation is one of the classic macroeconomic problems that the government must control every year. Inflation causes instability in the country's economy and will impact the operations of existing companies. The results show that inflation has a significant negative effect on stock prices in the mining sector during the 2015-2019 period. The results provide an understanding that high inflation will affect stock prices and cause stock prices to fall as well. Apart from looking at the company's inner side, such as financial performance, the investor's assessment also looks at the outer side, such as inflation. High inflation causes an increase in operating costs, input costs for companies, and a decrease in purchasing power of goods. An increase in costs will allow companies to increase prices and decrease company income. Some investors will prefer to invest in gold and the financial market compared to the stock market, which has no clarity in the future.

Interest rates, as well as inflation, hurt stock prices. This study shows that interest rates have a significant adverse effect on stock prices in the mining sector for the 2015-2019 period. The effect of interest rates can be seen from two sides to the company's stock price and company finances. First, when interest rates are set to rise, the company will reduce the company's debt because the debt burden will increase if borrowing. The capital structure will be affected, and the estimated future cash flows will decrease, lowering the stock price. Second, an increase in interest rates will make investors more interested in shifting their capital to interest rates because they are higher and safer than stocks. High-interest rates can also be profitable for companies if the company is in the financial sector. The results of this study are supported by research from (Widiastuti et al., 2016).

\section{Conclusion}

The conclusion in this study is that the liquidity ratio (CR) and solvency (DER) have no significant effect on stock prices of mining sector companies in 2015-2019. The variable profitability (ROE), valuation ratio (PBV) was concluded to have a significant positive effect on stock prices of mining sector companies in 2015-2019. Meanwhile, inflation and interest rates have a significant adverse effect on stock prices of mining sector companies in 2015-2019.

\section{Acknowledgments}

The authors would like to thank you for the feedback and support from academics. Similar to the financial support from the government. In this case the department of education and culture of the Republic of Indonesia. Without their support and attention, the project would not have been done so far. 


\section{References}

Al-Marhubi, F. (1997). A note on the link between income inequality and inflation. Economics Letters, 55(3), 317319. https://doi.org/10.1016/S0165-1765(97)00108-0

Amaliah, M. R., \& Manda, G. S. (2021). The Effect Of Debt To Equity Ratio, Return On Assets And Inflation On Stock Prices Of Oil And Gas Mining Companies 2014-2019. Jurnal Riset Akuntansi Terpadu, 14(1).

Căpraru, B., \& Ihnatov, I. (2014). Banks' profitability in selected Central and Eastern European countries. Procedia Economics and Finance, 16, 587-591. https://doi.org/10.1016/S2212-5671(14)00844-2

Cathelia, N., \& Sampurno, R. D. (2016). Analisis Pengaruh ROE, DER, TATO, CAPEX dan NCCR Terhadap Harga Saham (Studi Kasus Pada Perusahaan Manufaktur Sektor Industri Barang Konsumsi yang Terdaftar di Bursa Efek Indonesia Periode 2010-2014) (Doctoral dissertation, Fakultas Ekonomika dan Bisnis).

Decminar, Y., \& Widyarti, E. T. (2016). Analisis Pengaruh CR, TATO, ROE, DER Dan PER Terhadap Harga Saham (Studi Kasus pada Perusahaan Sektor Property dan Real Estate yang Terdaftar di BEI Periode 20112014) (Doctoral dissertation, Fakultas Ekonomika dan Bisnis).

Efrizon, E. (2019). Pengaruh Rasio Keuangan Terhadap Harga Saham Perusahaan Otomotif Periode 20132017. Jurnal Akuntansi Aktual, 6(1), 250-260.

Ferdinand, A. (2014). Metode Penelitian Manajemen: Pedoman Penelitian untuk Penulisan Skripsi Tesis dan Desrtasi Ilmu Manajemen.

Gonçalves, C. E. S., \& Salles, J. M. (2008). Inflation targeting in emerging economies: What do the data say?. Journal of Development Economics, 85(1-2), 312-318. https://doi.org/10.1016/j.jdeveco.2006.07.002

Halim, B. D., \& Hafni, L. (2019). Pengaruh Rasio Keuangan Terhadap Harga Saham Perusahaan Otomotif Dan Komponennya Yang Terdaftar Di BEI Periode 2014-2017. Bilancia: Jurnal Ilmiah Akuntansi, 3(4), 451-463.

Hassan, M. K., Khan, A., \& Paltrinieri, A. (2019). Liquidity risk, credit risk and stability in Islamic and conventional banks. Research in International Business and Finance, 48, 17-31. https://doi.org/10.1016/j.ribaf.2018.10.006

Hastuti, N., \& Sutanto, A. (2017). Analisis Pengaruh Rasio Keuangan Terhadap Harga Saham Pada Perusahaan Otomotif Yang Tercatat di Bursa Efek Indonesia (BEI) Periode 2012-2014. Jurnal Fokus Manajemen Bisnis, 7(2), 144-155.

Ichsani, S., \& Suhardi, A. R. (2015). The effect of return on equity (ROE) and return on investment (ROI) on trading volume. Procedia-Social and Behavioral Sciences, 211, 896-902. https://doi.org/10.1016/j.sbspro.2015.11.118

Itabillah, E.A. (2012). Pengaruh CR, QR, NPM, ROA, EPS, ROE, DER dan PBV terhadap Harga Saham Perusahaan Property dan Real Estate yang terdaftar di BEI. Fakultas Ekonomi. Universitas Maritim Raja Ali Haji.

Lee, K. H. (2011). The world price of liquidity risk. Journal of Financial Economics, 99(1), 136-161. https://doi.org/10.1016/j.jfineco.2010.08.003

Martiani, N. L. D. (2019). Pengaruh rasio keuangan terhadap harga saham pada perusahaan manufaktur sektor industri barang konsumsi yang terdaftar di bursa efek indonesia periode tahun 2013-2016. Jurnal Pendidikan Ekonomi Undiksha, 10(2), 668-678.

Niemann, M., Schmidt, J. H., \& Neukirchen, M. (2008). Improving performance of corporate rating prediction models by reducing financial ratio heterogeneity. Journal of Banking \& Finance, 32(3), 434-446. https://doi.org/10.1016/j.jbankfin.2007.05.015

Patar, A. (2014). Faktor Internal dan Eksternal yang Mempengaruhi Pergerakan Harga Saham (Studi Pada SahamSaham Indeks LQ45 Periode 2009-2013). Jurnal Administrasi Bisnis, 11(1).

Restiyanti, D. (2006). Analisis Pengaruh Faktor Fundamental Terhadap Return Saham (Studi Kasus Pada Perusahaan Otomotif Dan Komponennya di BEJ Periode 2001-2004. Universitas Diponegoro Semarang, Indonesia.

Rizal, S.S. (2015). Pengaruh Rasio Keuangan Terhadap Harga Saham Sektor Properti dan Real Estate pada Bursa Efek Indonesia. Jurnal Bisnis dan Komunikasi 2.

Rudebusch, G. D. (2002). Term structure evidence on interest rate smoothing and monetary policy inertia. Journal of monetary economics, 49(6), 1161-1187. https://doi.org/10.1016/S0304-3932(02)00149-6

Sack, B., \& Wieland, V. (2000). Interest-rate smoothing and optimal monetary policy: a review of recent empirical evidence. Journal of Economics and Business, 52(1-2), 205-228. https://doi.org/10.1016/S0148-6195(99)00030-2

Sari, I. A. G. D. M., \& Sedana, I. B. P. (2020). Profitability and liquidity on firm value and capital structure as intervening variable. International Research Journal of Management, IT and Social Sciences, 7(1), 116-127. https://doi.org/10.21744/irjmis.v7n1.828

Sudirjo, F. (2017). Pengaruh Analisis Rasio Keuangan, Rasio Pasar dan Kebijakan Deviden Terhadap Harga Saham (Studi Empiris pada Perusahaan Kelompok Saham LQ-45 di BEI). Serat Acitya, 5(2), 1. 
Sugosha, M. J., \& Artini, L. G. S. (2020). The role of profitability in mediating company ownership structure and size of firm value in the pharmaceutical industry on the Indonesia stock exchange. International Research Journal of Management, IT and Social Sciences, 7(1), 104-115. https://doi.org/10.21744/irjmis.v7n1.827

Sylvester, O., \& Ade, O. S. (2018). Revenue allocation in Nigeria: implications for sustainable national development. International Journal of Social Sciences, 1(1), 31-41. https://doi.org/10.31295/ijss.v1n1.15

Toin, D. R. Y., \& Sutrisno, S. (2016). Pengaruh Faktor Internal Dan Eksternal Terhadap Harga Saham Industri Perdagangan Eceran Di Bursa Efek Indonesia. Among Makarti, 8(2).

Ulupui, I. G. K. A. (2007). Analisis pengaruh rasio likuiditas, leverage, aktivitas, dan profitabilitas terhadap return saham (studi pada perusahaan makanan dan minuman dengan kategori industri barang konsumsi di BEJ). Jurnal Akuntansi dan Bisnis, 2(1), 88-102.

van der Ploeg, F. (1995). Solvency of counter-cyclical policy rules. Journal of Public Economics, 57(1), 45-65. https://doi.org/10.1016/0047-2727(94)01437-S

Widayanti, R., \& Colline, F. (2017). Pengaruh Rasio keuangan Terhadap harga saham Perusahaan lq 45 periode 2011-2015. Bina ekonomi, 2l(1), 35-49.

Widiastuti, S. A., Yunita, I., \& Gustyana, T. T. (2016). Analisis Faktor Internal Dan Eksternal Serta Pengaruhnya Terhadap Harga Saham Pada Perusahaan Pertambangan Yang Terdaftar Di Bursa Efek Indonesia Periode 20102014. eProceedings of Management, 3(1).

Widyarani, F. (2006). Pengaruh Faktor-Faktor Fundamental dan Makro Ekonomi Terhadap Nilai Return Saham Perusahaan Miscellaneous industries Tahun 2002-2003. Jurnal Riset Akuntansi Dan Bisnis. 